\title{
Isolation of viable Helicobacter pylori in the tonsillar tissues of chronic tonsillitis patients
}

\author{
Tri Wibawa ${ }^{1}$, Agus Surono², Irianiwati Widodo ${ }^{3}$ \\ Department of Microbiology ${ }^{1}$, Department of Otorhinolaryngology and Head-Neck Surgery ${ }^{2}$, and Department of \\ Anatomical Pathology ${ }^{3}$, Faculty of Medicine, Universitas Gadjah Mada, Yogyakarta, Indonesia, 55281
}

Key words: Viable Helicobacter pylori; tonsillar tissues; chronic tonsillitis

J Infect Dev Ctries 2011; 5(7):561-564.

(Received 09 February 2011 - Accepted 27 April 2011)

Copyright (C) 2011 Wibawa et al. This is an open-access article distributed under the Creative Commons Attribution License, which permits unrestricted use, distribution, and reproduction in any medium, provided the original work is properly cited.

Helicobacter pylori is a Gram-negative, spiral, microaerophilic bacterium that originally colonizes the human stomach. Chronic H. pylori infection has been associated with chronic gastritis, peptic ulcer disease, atrophic gastritis, mucosa associated lymphoid tissue (MALT) lymphoma, and gastric cancer [1]. H. pylori has been also detected in the mouth and the middle ear as well as in tonsillar and adenoid tissues [2-5]. However, the relationship of $H$. pylori with the pathogenesis of diseases that involve these organs is controversial.

Accumulated reports show controversies regarding the role of $H$. pylori in oropharyngeal infection. The hypothesis that $H$. pylori can colonize tonsillar and adenoid tissue has not yet been well elucidated due to the difficulty in isolating viable $H$. pylori $[3,6,7]$. The results of this study indicate that viable $H$. pylori can be detected in the tonsillar tissues of chronic tonsillitis patients using a combination of conventional culture and histological examination employing modified Giemsa staining and immunohistochemistry.

The study included nineteen patients with chronic tonsillitis who were admitted for elective tonsillectomy. Patients were evaluated as having chronic tonsillitis based on Ballantyne and Groves criteria [8] . All patients underwent tonsillectomy under general anesthesia. The tonsillar tissues were divided in two parts and subsequently used for microbiological and histological analysis. Informed consent was obtained from all patients or their parents.
Specimens obtained from patients were directly inoculated into Stuart transport medium. Soon after arriving at the laboratory, specimens were inoculated directly on Trypton Soy Agar (TSA) medium (Oxoid Ltd, Cambridge, UK) supplemented with 5\% defibrinated sheep blood and $H$. pylori selective Skirrow's medium supplemented with vancomycin, trimethoprim, polymyxin B, and amphotericin B (Sigma-Aldrich, St. Louis, USA). Plates were incubated micro-aerobically using the gas generating kit (Mitsubishi Gas Chemical Co Inc, Tokyo, Japan) at $37^{\circ} \mathrm{C}$ for 5 to 7 days. Colonies of suspected $H$. pylori were identified by Gram and Giemsa staining, and a positive reaction of the urease test.

Tonsillar tissue samples were fixed in $10 \%(\mathrm{v} / \mathrm{v})$ formalin, then embedded in paraffin, and subsequently used for modified Giemsa staining and immunohistochemistry. Modified Giemsa staining was performed according to the standard procedure described elsewhere [9]. Immunohistochemistry detection was performed using a specific $H$. pylori antibody (Dako, Glostrup, Denmark) Briefly, tissue sections were immersed in $10 \mathrm{mmol} / \mathrm{L}$ sodium citrate buffer, $\mathrm{pH} 6.0$, and then autoclaved at $120^{\circ} \mathrm{C}$ for 10 minutes. The sections were then treated with $3 \%$ $\mathrm{H}_{2} \mathrm{O}_{2}$ for 10 minutes at room temperature to inactivate endogenous peroxidase, and then they were blocked with $10 \%$ goat serum for 20 minutes at room temperature. The sections were incubated with a- $H$. pylori Ab (Dako, Glostrup, Denmark) overnight at $4^{\circ} \mathrm{C}$. The sections were washed with PBS and incubated for 20 minutes with biotinylated goat antirabbit IgG (Dako, Glostrup, Denmark). The sections 
Figure 1a. Giemsa staining of $H$. pylori colonies cultured on selective medium

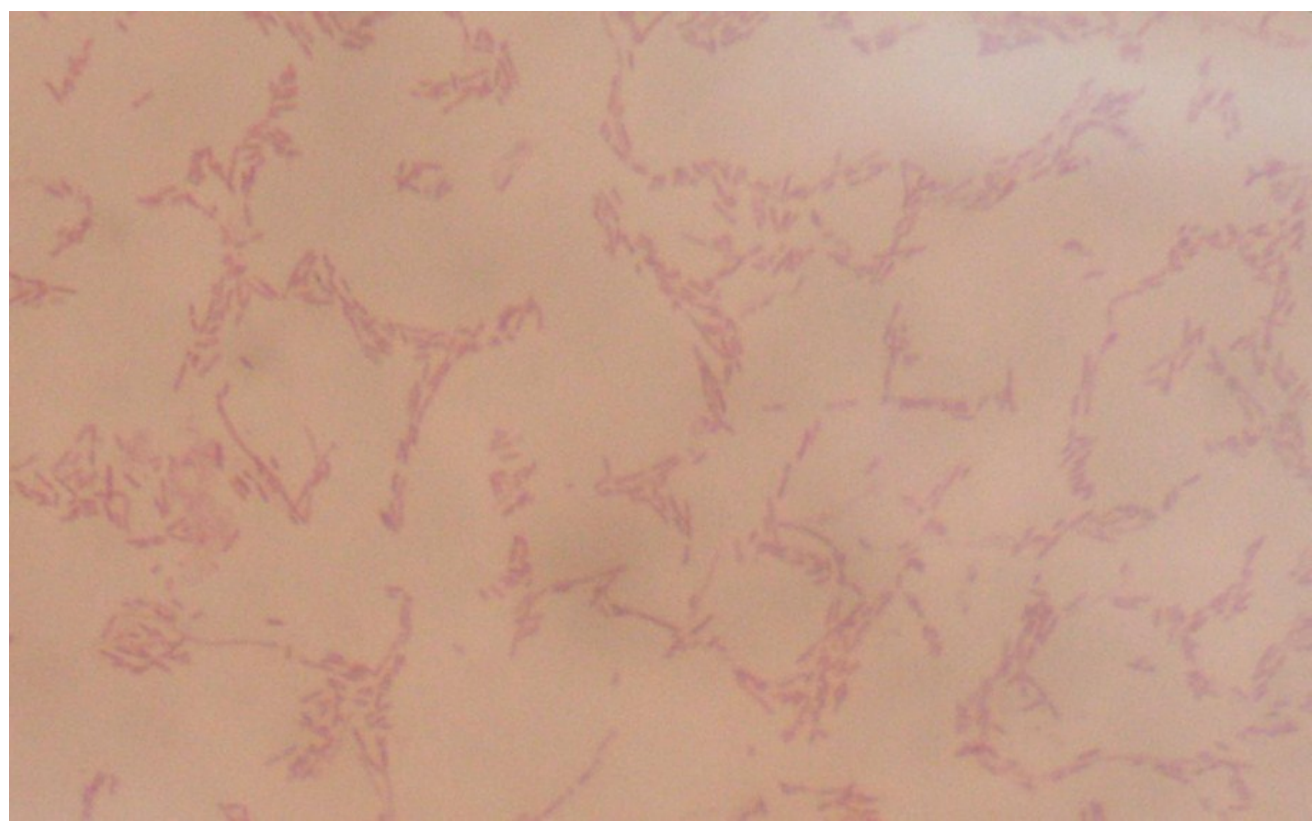

Figure 1b. Modified Giemsa staining of tonsillar tissue taken from patients with chronic tonsillitis (1000 x magnification)

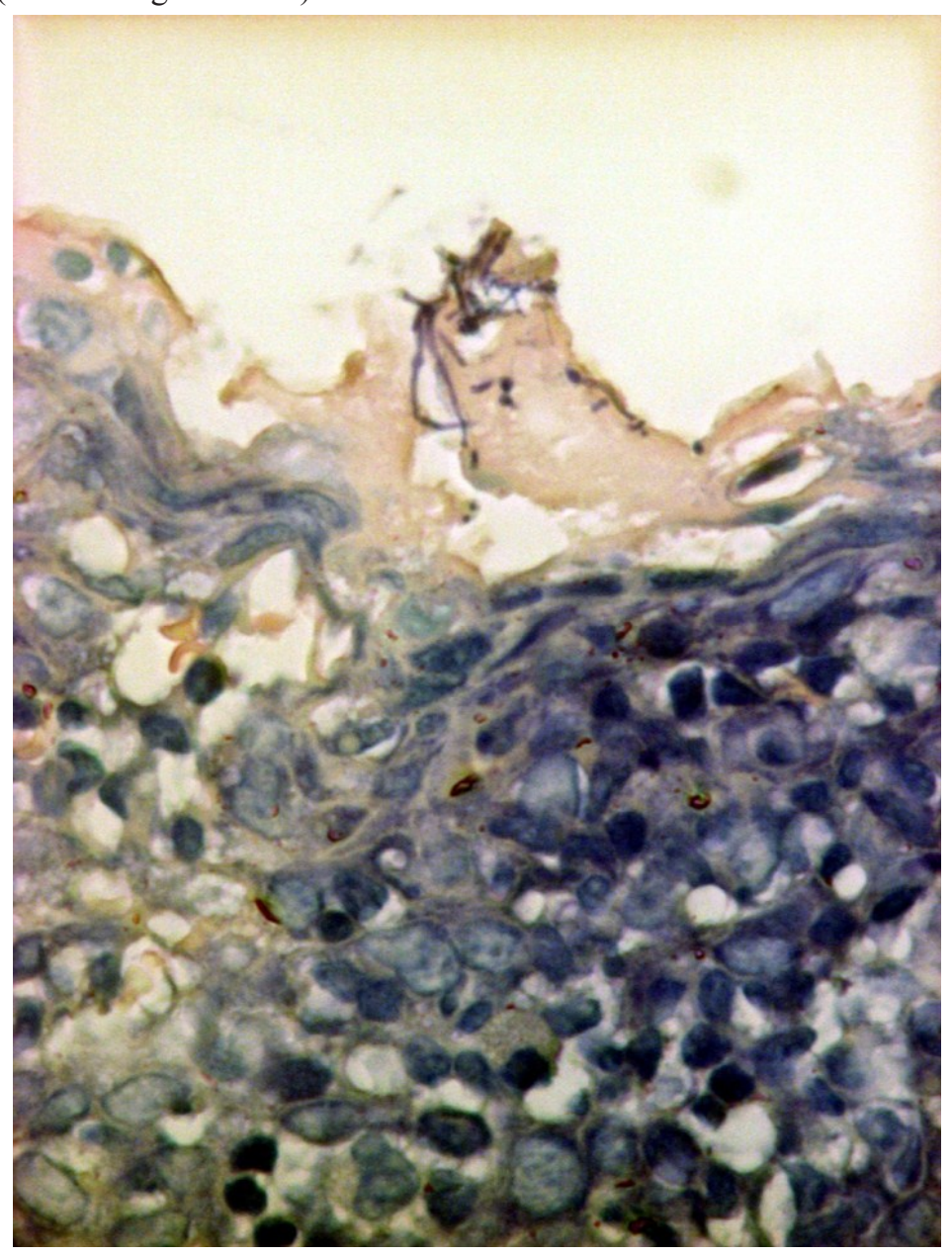


Figure 1c. Detection of $H$. pylori using immunohistochemistry

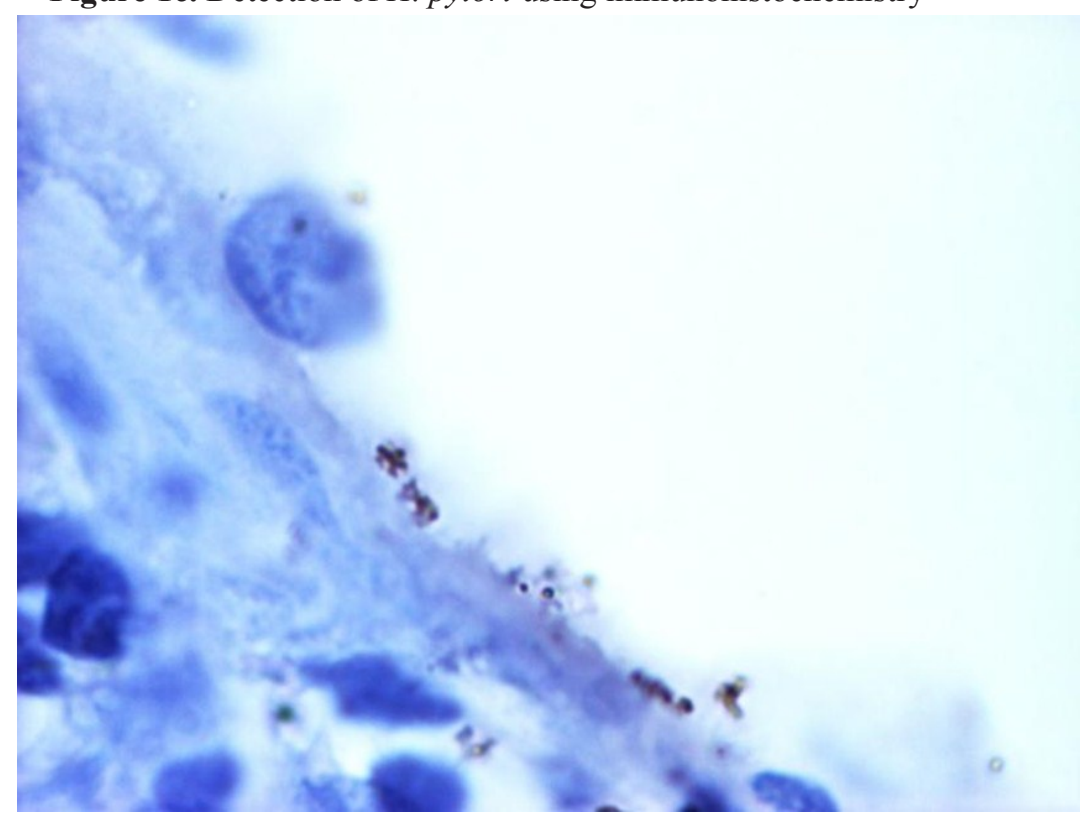

were washed again with PBS and incubated in a solution of avidin-conjugated horseradish peroxidase (Dako, Glostrup, Denmark) for 20 minutes, and then washed with PBS for 5 minutes. Peroxidase activity was detected with $\mathrm{H}_{2} \mathrm{O}_{2}$ /diaminobenzidine substrate solution. The sections were counterstained with hematoxylin before dehydration and mounted.

Viable $H$. pylori was detected by conventional culture in three male patients out of 19 patients $(15.7 \%)$ and confirmed by histology using modified Giemsa staining and immunohistochemistry (Figure 1). Culture results were in $100 \%$ agreement with modified Giemsa staining and immunohistochemistry results.

Culture is the gold standard method for the determination of $H$. pylori. It indicates the presence of viable bacteria, though several factors may lower its sensitivity, such as antibiotic administration, local disinfection, and anesthetic application. Modified Giemsa staining and immunohistochemistry staining were used to confirm culture results due to their superior and reproducible capability to detect $H$. pylori in tissue samples.

Some studies have suggested that $H$. pylori may have an association with oropharyngeal infection $[3,4,7]$. However, this notion was not supported by the work of several groups which were not able to detect the colonization of $H$. pylori in tonsillar tissue $[6,10]$. These contradictory results may be due to the specific characteristics of each study population or to the variety of methods employed in the studies. Yilmaz et al. [5] were the first who isolated H. pylori from tonsillar tissue cultures from patients suffering from otitis media with effusion. Our study appears to be the first reporting isolation of viable $H$. pylori from the tonsillar tissues of patients with chronic tonsilitis. Eyigor et al. [11] reported that $H$. pylori can be detected in tonsillar tissue of $5.5 \%$ of chronic tonsillitis patient by rapid urease test (RUT) but not with PCR. Vayisoglu et al. [12] detected H. pylori using RUT in only $2.2 \%$ of adenoidectomy specimens and in none of the tonsillectomy specimens. A positive result was not obtained in any tonsillectomy specimen using immunohistochemistry. Our results showed $H$. pylori colonization in the tonsillar tissue of $15.7 \%$ of patients suffering from chronic tonsillitis. The different findings may be related to distinct population characteristics. The combination of culture and histological examination may be useful in detecting $H$. pylori colonization of tonsillar tissue in chronic tonsillitis cases.

\section{Acknowledgments}

This work was partly supported by a research grant from the Faculty of Medicine, Universitas Gadjah Mada, Yogyakarta, Indonesia. 


\section{References}

1. Dunn BE, Cohen H, Blaser MJ (1997) Helicobacter pylori. Clin Microbiol Rev 10: 720-741.

2. Allaker RP, Young KA, Hardie JM, Domizio P, Meadows NJ (2002) Prevalence of Helicobacter pylori at oral and gastrointestinal sites in children: evidence for possible oralto-oral transmission. J Med Microbiol 51: 312-317.

3. Cirak MY, Ozdek A, Yilmaz D, Bayiz U, Samim E, Turet S (2003) Detection of Helicobacter pylori and its cagA gene in tonsil and adenoid tissues by PCR. Arch Otolaryngol Head Neck Surg 129:1225-1229.

4. Bulut Y, Agacayak A, Karlidag C, Toraman ZA, Yilmaz M (2006) Association of cag $A^{+}$Helicobacter pylori with adenotonsilar hypertrophy. Tohoku J Exp Med 209: 229233.

5. Yılmaz T, Ceylan M, Akyön Y, Ozçakyr O, Gürsel B (2006) Helicobacter pylori: A possible association with otitis media with effusion. Otolaryngol Head Neck Surg 134: 772-777.

6. Jelavic B, Bevanda M, Ostojic M, Leventic M, Vasilj M, Knezevic E (2007) Tonsillar colonization is unlikely to play important role in Helicobacter pylori infection in children. Int J Pediatr Otorhinolaryngol 71: 585-590.

7. Kusano K , Tokunaga O, Ando T, Inokuchi A (2007) Helicobacter pylori in the palatine tonsils of patients with IgA nephropathy compared with those of patients with recurrent pharyngotonsillitis. Hum Pathol 38: 1788-1797.
8. Ballantyne J, Groves J (1979) Diseases of the Ear, Nose and Throat. Fourth ed. London: Butterworths. $132-134$.

9. Rotimi O, Cairns A, Gray S, Moayyedi P, Dixon MF (2000)Histological identification of Helicobacter pylori: comparison of staining methods. J Clin Pathol 53:756-759.

10. Pitkäranta A, Kolho KL, Rautelin H (2005) Helicobacter pylori in children who are prone to upper respiratory tract infections. Arch Otolaryngol Head Neck Surg 131: 256-258.

11. Eyigor M, Eyigor H, Gultekin B, Aydin N (2009) Detection of Helicobacter pylori in adenotonsiller tissue specimens by rapid urease test and polymerase chain reaction. Eur Arch Otorhinolaryngol 266: 1611-1613.

12. Vayisoglu Y, Ozcan C, Polat A, Delialioglu N, Gorur, K (2008) Does Helicobacter pylori play a role in the development of chronic adenotonsillitis? Int $\mathrm{J}$ Pediatr Otorhinolaryngol 72: 1497-1501.

\section{Corresponding author}

Tri Wibawa, MD, PhD

Department of Microbiology

Faculty of Medicine, Universitas Gadjah Mada

J1. Kesehatan, Yogyakarta, Indonesia 55281

Telephone: +62274580297

Fax: +62274581876

Email: twibawa@ugm.ac.id

Conflict of interests: No conflict of interests is declared. 